のものが数百 $\mathrm{mg} / \mathrm{l}$, 組立作業者のもので $75 \mathrm{mg} / \mathrm{l}$ 它こ えるものが約20\%にみられた。

トリクレン曝露者の主訴としては，かすえでみえる， みにくい，複視などの視機能の障害を思わせる訴えが約 半数にみられ，ついで，めまい，頭痛，疫学感を訴える ものが多い。

身体検查では, 視野の狭窄のほか, 血液では血液比重, $\mathrm{Hb}$ 值の低下，血清蛋白分劃で Albumin の減少， $\gamma$ Globulin の増加为認められ，尿蛋白，ウロビリノーゲ ン陽性, Vacato：N 增加扔よび Uropepsin 減少等, 蛋白代謝之関係の尚る代謝異常が特に印象づけられた。

\section{9. トリクレン曝露者の所謂疲労検査成綪}

高松 誠（電麗公社）

職場の環境条件改善のため, 勧告の資料となすために

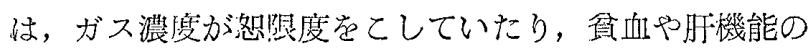
障害がみられるということのほかに，それらの不良がス 環境が，作業能率を低下せしめているという資料を整光 るてとは，意外なほど效果のあるここがある。こてに述 べる成績も，それらの意図のもとに前記，トリクレン職 場について，いわゆる疲学検查を実施したものである。

まず被検者を同一年令分布で抽出し，つぎの 3 群にわ けた。

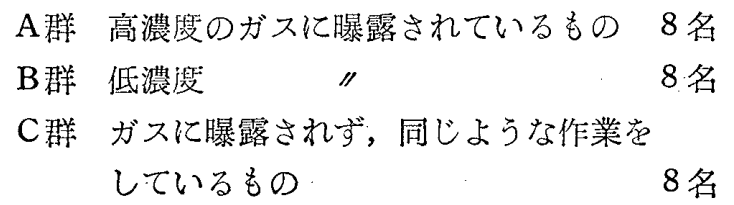

被検者の主訴として，視機能はの障害を思わせる所見 が多かったので，検查項目としては，眼の機能をみるて とに重点をおいた。即ち，ちらつ值，近点距㕍，色名 呼称, 嚗蓋腱反射および二点弁別の 5 項目である。

調查結果は，予期のと打りに，高浱度のトリクレンガ スに懪露されているものほど，機能の低下が藷明であっ た。視嘰能では，とくに近点距離の成績が週末の金㺟日 では，逐時的に延長し，作業後，A群では65\%，B群で は40\%，C群では15\%の延舆をしめした。てれらの成績 は，環境改善のため有効に生かされた。

\section{Trychioroethylene と Curing Solution の毒 性に関する研究}

松田 昭（岡山大・公珮）

1) Trychloroethylene の毒性について, 、ウスを 用い， $L D_{50}$ を求め，つぎの結果を得た。

$\mathrm{LD}_{50}$ 注腹腔内注射第 1 日目は $3,6945 \pm 0.17095$ $\mathrm{mg} / \mathrm{g}, \mathrm{LD}_{50}$ は腹腔内注射第 2 日目は $2,8741 \pm 0.16524$

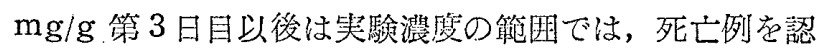
めなかった。なお Tetrachloethlene の毒坐は同容量 では Trychloroethylene に比し，多少強い傾向が認 められた。

2) ダイメットコート用 Curing Solution の毒性に ついて, マウスを使用して, $L_{50}$ を求》, つぎの結果 を得记。

$\mathrm{LD}_{50}$ は注射第 1 日目は $0.45185 \pm 0.11737 \mathrm{mg} / \mathrm{g}$ ，第 2 日目以後には死亡例葆認めなかった。なお Curing Solution の成分と考壳られる Isopropyl Alcohol と Aceton 混合液の毒性について，マウスを使用して， $\mathrm{LD}_{50}$ 学求めた結果では，注射第 1 日目は，3.43512 士 $0.089232 \mathrm{mg} / \mathrm{g}$ ，注第射 2 日目は $3,07866 \pm 0.08697$ $\mathrm{mg} / \mathrm{g}$, 示し, Curing Solution に比較して, 低い毒 性を示した。

3) なお Trychloroethylene の動物吸人装植を試作 して，笑験を行なっているので，あわせて発表する予定 である。

281. 工業用神経毒に関する研究 (10) トリクロールエ

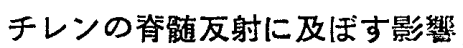

東田敏夫，佐々木登志恵，永沢登喜子 （関西医大・衛生）

トリクレンは工業用溶剂として用いられるほか，無痛 分婏麻醉剂として，座科にてひらく用いられている。

ての薬物の神経系侵害作用を検討する目的で，か悋て より本研究室において奏施している筋電図学的方法によ って研究した。

無麻醉の正常躳およご脊檤雨について，脛骨神経の中 枢断端に矩形波単一刺激 $(0.1 \mathrm{msec})$ をあたえ，同側の 前脛骨筋より針電㥛により，侵害反射放雷を誘導した。

トリタレンは $0.05 \mathrm{cc} / \mathrm{kg}$ ま゙た $0.1 \mathrm{cc} / \mathrm{kg}$ を耳静眽 より徐々に注射した。

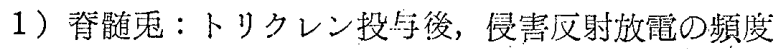
並ごに電位が低下しついに全く消失する。しかし死亡例 老除き，㭙間の経過とともに回復する。トリタレン投与 量が多い場合は，侵害反射放電の消失が早く，关の回復 が打くれる傾向兮市る。

2）正常鬼：トリクレン投与後，侵害反射放霓の頻度: 並びに電位が低下し，ついに全く消失するが，時間の経 過とともに回復し，脊䯣息よりも早く回復する㖽向があ る。

即ち,トリタレン注沶剈道介在細胞並びに高次神経中枢 